Instytut Archeologii

Uniwersytet Mikołaja Kopernika

$w$ Toruniu

http://dx.doi.org/10.12775/AHP.2014.003

WOJCIECH CHUDZIAK

\title{
Długi wiek XIII w Chełmnie
}

\section{The 'long' $13^{\text {th }}$ century in Chelmno}

Zarys treści. W artykule przedstawione zostały dzieje Chełmna, centralnego ośrodka ziemi chełmińskiej, w okresie od 2. połowy XII do 1. połowy XIII wieku. W jego historii skupiają się zasadnicze przeobrażenia społeczno-gospodarcze i polityczne, składające się na symboliczne „długie” trwanie XIII wieku. Warto podkreślić stołeczną rangę tego ośrodka pełniącego - niezależnie od zmieniających się uwarunkowań prawno-ustrojowych - centralne funkcje polityczne, religijne, społeczno-gospodarcze i kulturotwórcze.

Stowa kluczowe: ziemia chełmińska, urbanizacja, Kałdus, Chełmno, ośrodek kasztelański, miasto krzyżackie, wymiana, rzemiosło, wczesne średniowiecze, późne średniowiecze, źródła archeologiczne, źródła pisane.

Złożone procesy zachodzące w północno-zachodniej części Słowiańszczyzny w XIII wieku, zasadniczo zmieniające dotychczasowy, tradycyjny model funkcjonowania społeczności, obejmowały wiele sfer ówczesnego życia, włącznie z zasadniczymi przeobrażeniami społeczno-gospodarczymi i politycznymi (ryc. 1). W przypadku pogranicznej ziemi chełmińskiej usytuowanej między Mazowszem, Kujawami, Pomorzem Wschodnim i pruską Pomezanią, w swej strukturze nawiązującej do niemieckich marchii, procesy te scharakteryzować można byłoby kilkoma słowami kluczowymi takimi jak ,feudalizacja”, „decentralizacja/ /centralizacja”, „kolonizacja” czy „urbanizacja”. Jak wiadomo w skali północno-zachodniej części Słowiańszczyzny przebiegały one niejednakowo w czasie i w przestrzeni, na ziemi chełmińskiej ujawniły się w 1 . połowie XIII wieku bardzo wyraziście, zwłaszcza na tle konfliktów charakterystycznych dla terytoriów pogranicznych, przede wszystkim najazdów plemion bałtyjskich (początkowo 


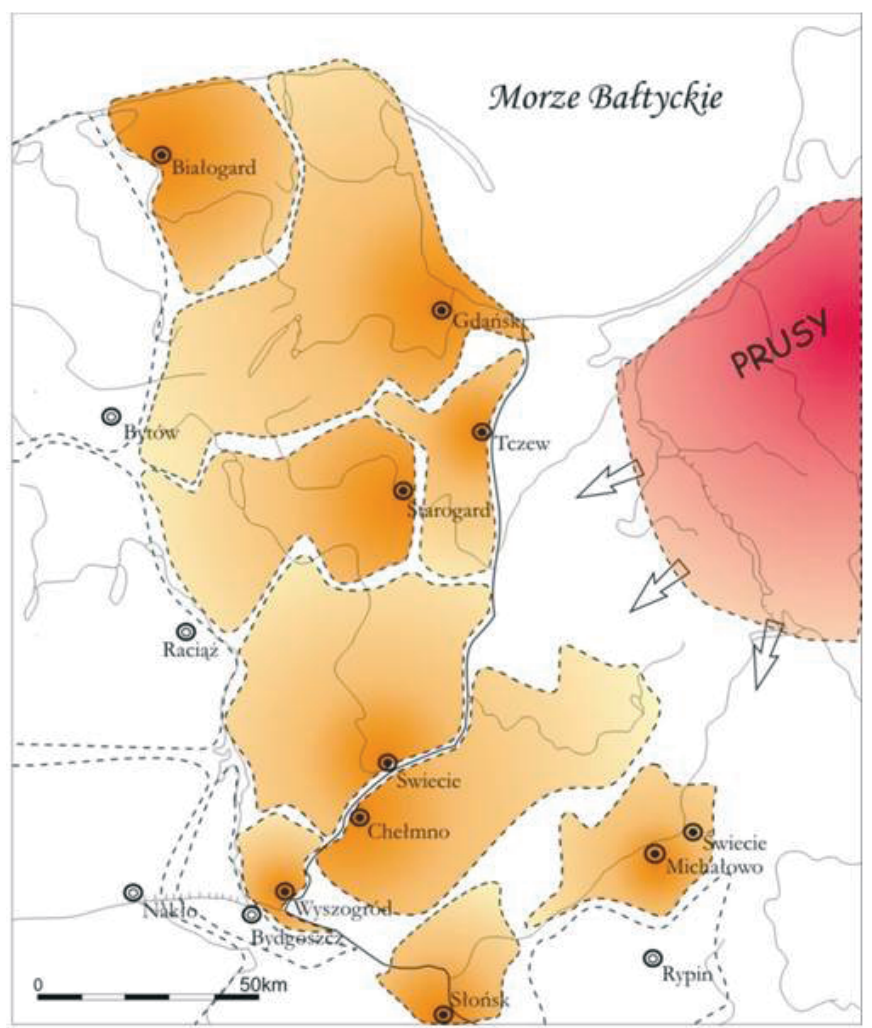

1-๑ 2-๑ 3-:

Ryc. 1. Zasięg kasztelanii na Pomorzu Nadwiślańskim u schyłku wczesnego średniowiecza (zgeneralizowane ujęcia na podstawie Powierski 1973 oraz Ślaski 1960)

Fig. 1. Range of castellanies in Eastern Pomerania at the end of the Early Middle Ages (generalized approach based on Powierski 1973 and Ślaski 1960)

pruskich, później jaćwieskich, litewskich), ale również utarczek z księciem pomorskim Świętopełkiem. Sytuacja społeczno-polityczna na opisywanym obszarze była niestabilna, niesprzyjająca trwałemu osadnictwu, co wydaje się, że zostało odzwierciedlone zarówno w źródłach archeologicznych, jak i pisanych. Również wyniki badań palinologicznych wskazują na brak stabilizacji osadniczej w tym okresie, mogącej doprowadzać niejednokrotnie do częściowej depopulacji tych terenów (Noryśkiewicz 2013).

Umowna cezura pomiędzy wczesnym a późnym średniowieczem często łączona jest w przypadku ziemi chełmińskiej z 1228 rokiem i przekazaniem tego terenu przez Konrada Mazowieckiego zakonowi krzyżackiemu. Wydaje się jednak, że w rzeczywistości to nie przybycie nad Wisłę w okolice Nieszawy trzy lata później siedmiu braci zakonnych, wzmocnionych posiłkami mazowieckimi, 
miało znaczenie ,przełomowe” dla losów ziemi chełmińskiej, ale dalsze implikacje decyzji piastowskiego księcia i stopniowa, po części ewolucyjna budowa nowego, scentralizowanego modelu ustroju państwowego charakterystycznego dla Zakonu w późniejszym okresie.

Wydarzenia z 1228 roku wpisują się w logiczny ciąg przyczynowo-skutkowy, którego genezę upatrywać należy jeszcze w połowie XII wieku, a ściślej w zwiększonej aktywności plemion pruskich na terenie Pomezanii, istniejącemu z tej strony zagrożeniu ziemi chełmińskiej i politycznym decyzjom podejmowanym na północnym pograniczu za czasów panowania Bolesława Kędzierzawego. W tradycji przekazanej przez Piotra Dusburga moment ten łączony może być z osobą Hugona Butyra, rycerza niderlandzkiego, który wsławił się w walkach z Prusami. Dzieje ziemi chełmińskiej w całym tym okresie (2. połowa XII-1. połowa XIII wieku), oświetlone stosunkowo dobrze w źródłach pisanych, prześledzić można zwłaszcza na przykładzie Chełmna, centralnego ośrodka tej strefy, eponimicznego jeżeli chodzi o nazwę całego regionu, co jednoznacznie podkreśla jego wyjątkowe znaczenie (ryc. 2). W historii tego ośrodka „wędrującego” w przestrzeni zgodnie z wolą ówczesnych decydentów, jak w soczewce skupiają się zasadnicze przeobrażenia społeczno-gospodarcze i polityczne, składające się na jego symboliczne „długie” trwanie. Położony przy skrzyżowaniu szlaków dalekosiężnych, na zachodnim obrzeżu międzyrzecza Wisły, Drwęcy i Osy, stanowił on przez długi okres „bramę” wejściową na ziemię chełmińską i centrum polityczne i społeczno-gospodarcze, któremu podlegała pograniczna peryferia, najpierw państwa polskiego w ramach organizacji kasztelańskiej, a następnie krzyżackiego, przynajmniej w pierwszym etapie jego funkcjonowania.

Na gruncie archeologii historycznej prześledzić można główne etapy rozwoju tego ośrodka, odnosząc się do zasadniczych treści źródeł pisanych, które pozwalają na interpretację kontekstu historycznego źródeł materialnych z nim wiązanych. Zasadniczą bazę do rekonstrukcji/interpretacji dziejów chełmińskiego ośrodka w XIII stuleciu stanowi kilka przekazów, między innymi dokument Konrada Mazowieckiego z 1223 roku (tzw. dokument z Lonyz), dokumenty lokacyjne Chełmna z 1233 i 1251 roku, wspomniana już kronika Piotra Dusburga zredagowana w XIV wieku i Roczniki Toruńskie. Z uwagi na charakter niniejszego przyczynku nie ma potrzeby ich szczegółowego omawiania, zwłaszcza, że każdy doczekał się wielu wnikliwych opracowań historycznych. Z lektury tych dokumentów wyłania się obraz rozwoju omawianego ośrodka, który we współczesnej historiografii znaleźć można w pracach Janusza Bieniaka (1970), Jana Powierskiego (1973), Tomasza Jasińskiego (1992), Zenona Nowaka (1987), Sławomira Jóźwiaka (1996) czy Romana Czai (2006). Generalnie przyjmuje się, że najstarsze, przedkolacyjne Chełmno, wymienione po raz pierwszy w tzw. falsyfikacie mogileńskim z 1075/1147 roku wśród nadań dla klasztoru benedyktyńskiego w Mogilnie, niemal do końca 1. ćwierci XIII wieku znajdowało się w miejscu, gdzie dzisiaj wznosi się Góra 


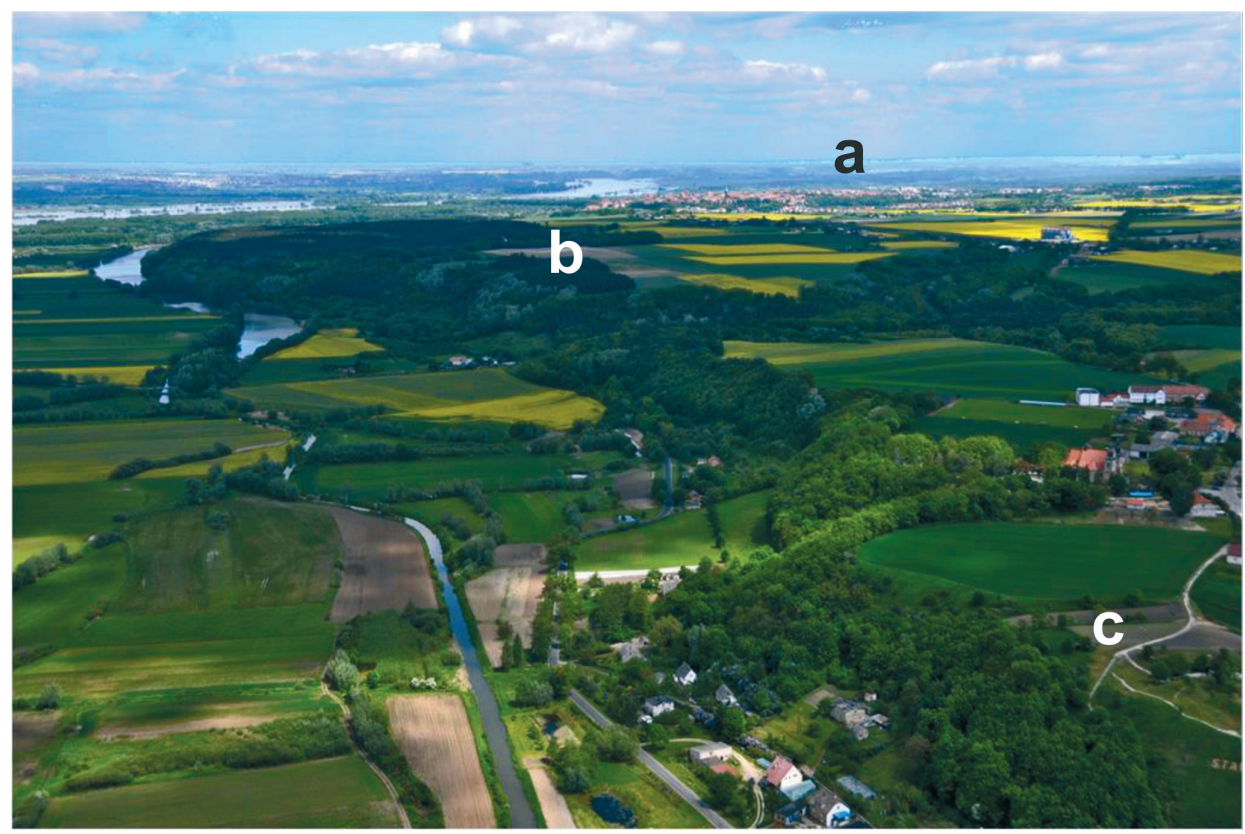

Ryc. 2. Widok na okolice Chełmna (a), Kałdusa (b) i Starogrodu (c) (fot. W. Stępień) Fig. 2. View of the Chełmno (a), Kałdus (b) and Starogród area (c) (photo W. Stępień) św. Wawrzyńca. Do niej odnieść należałoby siedzibę Hugona Butyra, zapewne kasztelana chełmińskiego, wsławionego w walce z Prusami, jak również gród przekazany przez Konrada Mazowieckiego biskupowi pruskiemu Chrystianowi, który uzyskał prawo do ulokowania w Chełmnie curii i konwentu biskupa misyjnego na Prusy (Powierski 1973, s. 7; na temat działalności biskupa-por. Wyrwa 2009, s. 95). Problem prawa własnościowego Chrystiana do Chełmna był przedmiotem licznych dyskusji prowadzonych zwłaszcza przez J. Bieniaka, J. Powierskiego i T. Jasińskiego. Z analizy tzw. dokumentu z Lonyz wynika, że Chełmno zostało księciu stosunkowo szybko zwrócone, a w 1223 roku ponownie stało się ośrodkiem kasztelańskim wraz ze zgodą biskupa na odbudowanie grodu przez krzyżowców z księciem Henrykiem śląskim na czele. Ostateczne fiasko tej politycznej i militarnej operacji sprawiło, że Konrad Mazowiecki postanowił powierzyć obronę ziemi chełmińskiej zakonowi krzyżackiemu, który w latach 1228-1230 uzyskał posiadanie i prawa władcze nad tym terytorium. Jak słusznie stwierdził Gerard Labuda był to kolejny etap w procesie decentralizacji władzy i rozdrobnienia feudalnego, związany ze szczególnym nasileniem najazdów pruskich (Powierski 1973, s. 89). Wraz ze stworzeniem państwa zakonnego na ziemi chełmińskiej pojawił się nowy model organizacji terytorialnej oparty na zamkach i miastach. Wystawiony w 1233 roku przez wielkiego mistrza zakonnego Hermana von Salza dokument, zwany później przywilejem chełmińskim, określał 
„gospodarcze i prawnoustrojowe warunki rozwoju gminy miejskiej" Chełmno. Mieszkańcom tego ośrodka nadano prawo magdeburskie - znacznie jednak złagodzone w wielu punktach - aby przyciągnąć osadników niemieckich. Na ogół przyjmuje się, że dokument ten dotyczył już nowej lokalizacji miasta wzniesionego wraz z zamkiem w 1232 roku przez Hermana Balka, mistrza krajowego Zakonu, na terenie dzisiejszego Starogrodu, około $1 \mathrm{~km}$ na południe od Góry św. Wawrzyńca, gdzie zlokalizowane było pierwotnie Chełmno (Jóźwiak 1996).

Z analizy źródeł pisanych wynika również, że dalsze losy Chełmna zmieniały się dość dynamicznie. Roczniki Toruńskie pod datą 1239 umieszczają jego pierwszą translokację ,w pobliże Wisły”, zatem musiało się ono znajdować w dzisiejszym Starogrodzie, niedaleko zamku, zapewne na jego bezpośrednim zapleczu. Kolejna translokacja miasta nastąpiła przed 24 listopada 1248 roku na obszar dzisiejszego przedmieścia Rybaki, a następnie w latach 1251-1253 na teren obecnego miejsca. W odnowionym dokumencie lokacyjnym z 1251 roku Zakon chciał, aby „miasto to było główne i godniejsze od pozostałych już założonych miast i tych, które mogą powstać pomiędzy Wisłą, Osą i Drwęcą", co w sposób oczywisty nawiązywało do stołeczności Chełmna w okresie piastowskim.

Nadrzędną rolę Chełmna w międzyrzeczu Wisły, Drwęcy i Osy potwierdzają również badania archeologiczne prowadzone intensywnie na ziemi chełmińskiej od wielu dziesięcioleci (Kola 1975; Chudziak 2003; 2010 - tam wcześniejsza literatura). Realizowane one są zasadniczo w dwóch osobnych nurtach tradycyjnie wyróżnianych w polskiej archeologii: jednym, dotyczącym osadnictwa wczesnośredniowiecznego oraz drugim, ukierunkowanym na rozpoznanie kultury okresu późnego średniowiecza, zasadniczo związanego z dziejami zakonu krzyżackiego na tym terenie. O ile jednak Góra św. Wawrzyńca i tereny bezpośrednio z nią związane są stosunkowo dobrze rozpoznane metodami archeologicznymi (ryc. 3), to zarówno teren Starogrodu, jak i dzisiejszego miasta wyglądają pod tym względem o wiele słabiej (ryc. 4, 5). W pierwszym przypadku prowadzone były jedynie badania sondażowe na terenie podzamcza, natomiast w drugim przedmiotem rozpoznania były niektóre punkty miasta, między innymi strefa przy kościele dominikańskim, czy też przy kościele farnym. Moderatorem tych prac był w latach 70. ubiegłego wieku Andrzej Kola z Katedry Archeologii UMK w Toruniu. Z perspektywy minionego czasu można tylko żałować, że później właściwie ich nie kontynuowano, przynajmniej w sposób planowy.

Końcowa faza funkcjonowania wczesnośredniowiecznego zespołu osadniczego w Kałdusie, identyfikowanego z piastowskim Chełmnem, wiąże się z występowaniem materiałów ceramicznych przyporządkowanych do ostatniej fazy rozwoju lokalnej wytwórczości garncarskiej (faza 9). W periodyzacji archeologicznej tego ośrodka obejmuje ona okres od połowy XII wieku do 1. ćwierci kolejnego stulecia. Z tego okresu pochodzą złożone i bogate nawarstwienia kulturowe występujące właściwie we wszystkich partiach badanego terenu, sąsiadującego bezpośrednio 


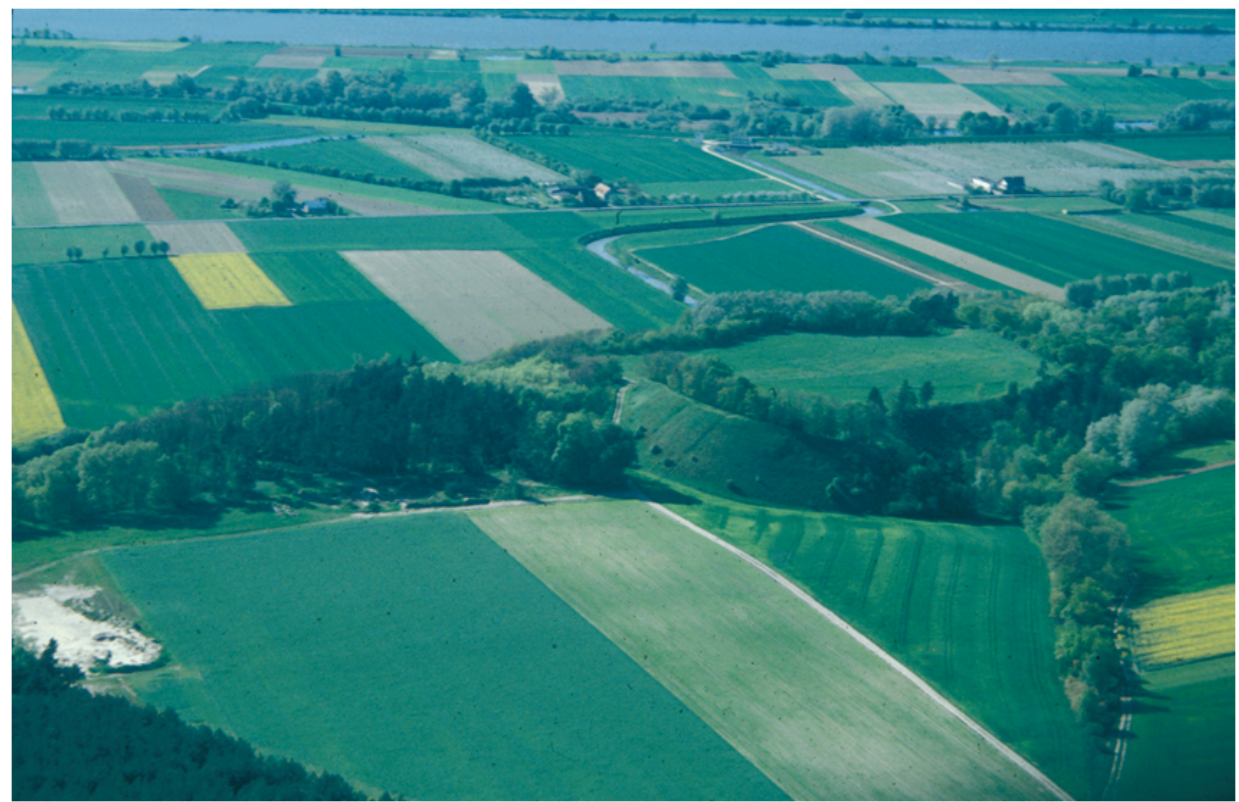

Ryc. 3. Widok na Górę św. Wawrzyńca w Kałdusie (fot. W. Stępień) Fig. 3. View of Mount St. Laurence in Kałdus (photo W. Stępień)

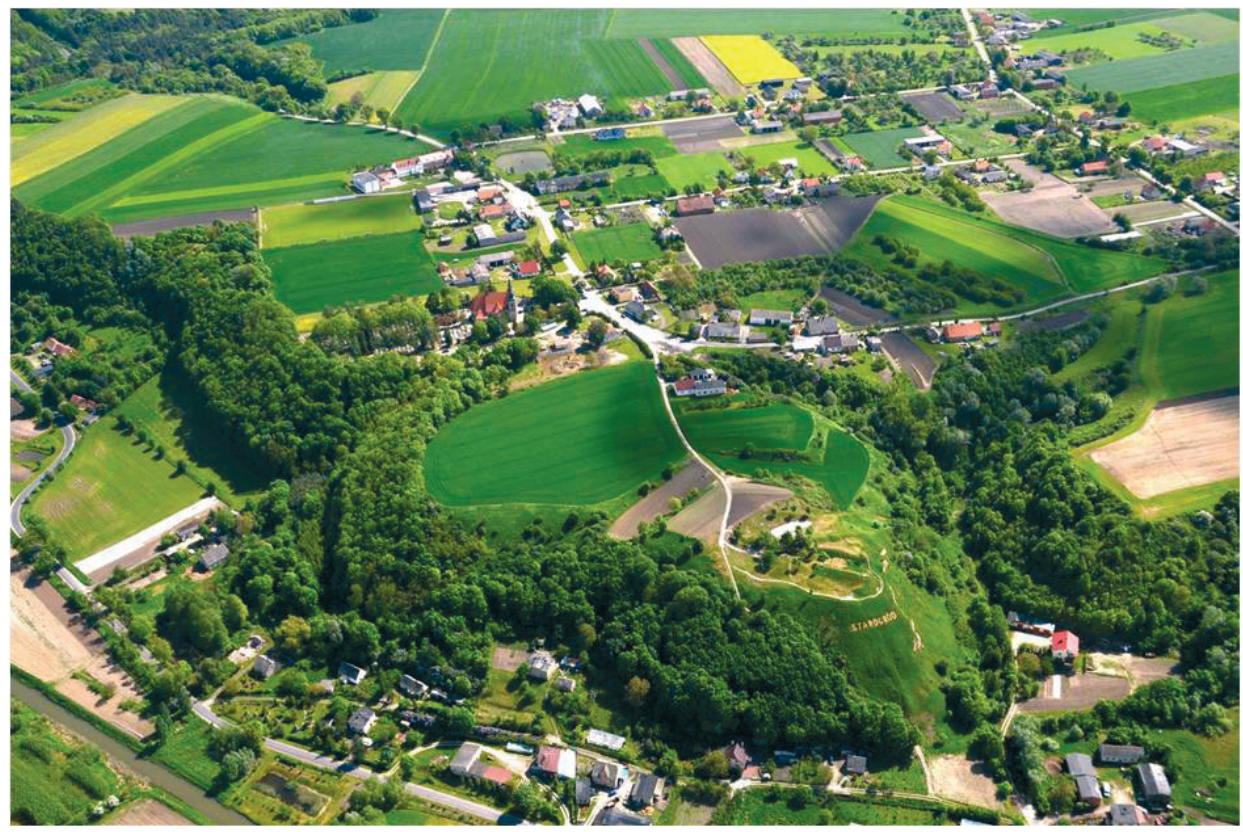

Ryc. 4. Widok na grodzisko i zamczysko w Starogrodzie (fot. W. Stępień) Fig. 4. View of the stronghold and the castle in Starogród (photo W. Stępień) 


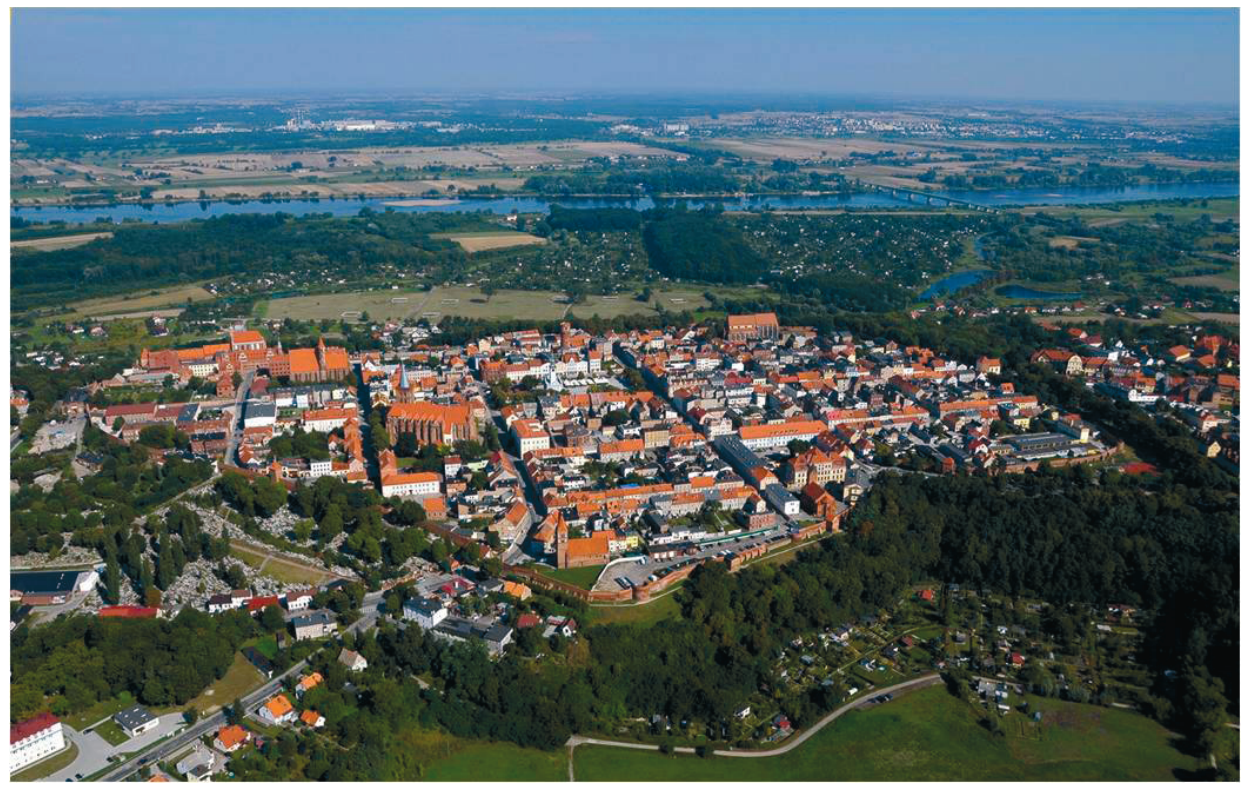

Ryc. 5. Widok na współczesne Chełmno z zachowanym średniowiecznym układem urbanistycznym (fot. W. Stępień)

Fig. 5. View of contemporary Chełmno with preserved medieval urban layout (photo W. Stępień)

z Górą św. Wawrzyńca. Rozpoznano je na północ od Góry, zarówno w obrębie tzw. gródka wewnętrznego, jak i północnej części grodziska, intensywnie występowały również na terenie osady podgrodowej, głównie w postaci licznych obiektów osadniczych stanowiących ponad 90\% liczby wszystkich jam stwierdzonych na tym stanowisku (ponad 300 jam). Na ten okres datowane są również liczne groby odsłonięte zarówno na terenie stanowiska 1, jak i stanowiska 4, tworzące najmłodszy horyzont użytkowania obu nekropolii (ponad 500 grobów).

Z uwagi na masowość materiału źródłowego oraz zasięg i miąższość warstw kulturowych, miejscami silnie przetworzonych w okresie krzyżackim sądzić należy, że funkcjonował wówczas dwuczłonowy gród, dodatkowo ufortyfikowany w części wewnętrznej (castrum maior i castrum minor). Bezpośrednio na zgliszczach zabudowy powstałej w 1. połowie XII wieku odkryto poziom z licznymi pozostałościami pieców, najpewniej służących do wytopu żelaza, o czym świadczą ich kształty oraz żużle odkryte w pobliżu. Podobną sytuację stwierdzono w obrębie castrum maior, blisko pozostałości kamiennej budowli sakralnej z XI wieku, gdzie w warstwie zalegającej częściowo na jej reliktach stwierdzono klasyczny piec kopułkowy z wlotem przeznaczony do wytopu żelaza. Piecowisko usytuowane w południowo-wschodniej części założenia przykryte zostało niwelacyjną warstwą gliny, na której wzniesiono nasyp wału ziemnego, prawdopodobnie zwieńczonego 
w górnej części palisadą. Obiekty wkopane w warstwę gliny, zalegające pod wałem wskazują, że stało się to w innym czasie. Pozycja stratygraficzna reliktów wału zalegających w najmłodszych poziomach związanych z IX fazą wskazuje, że pochodzi on dopiero z 1. ćwierci XIII wieku i nie jest wykluczone, że można go wiązać z działalnością biskupa Chrystiana lub - co bardziej prawdopodobne - z odbudową grodu w 1223 roku po zniszczeniach dokonanych przez Prusów w latach 1216-1217 (Wyrwa 2002; na temat misji pruskiej por. Wyrwa 2009, s. 74). W tym kontekście zespół pieców zalegających na reliktach starej zabudowy należałoby wiązać z produkcją żelaza i zwiększonym zapotrzebowaniem na ten surowiec wykorzystywany do wyrobu broni i narzędzi, niezbędnych na zdewastowanych terenach. Uruchomienie wytopu żelaza i produkcji w obrębie starego gródka, a nie osady podgrodowej byłoby wyrazem permanentnego zagrożenia istniejącego w tym czasie zapewne od strony Prusów. Być może z tego miejsca dostarczano materiały potrzebne do budowy i skutecznej ochrony stróży na pograniczu prusko-chełmińskim w okresie sukcesów militarnych Krystyna - wojewody Konrada Mazowieckiego.

W kontekście opisanych w źródłach wydarzeń dotyczących decyzji księcia Konrada o ulokowaniu w Chełmnie curii i konwentu biskupa misyjnego Chrystiana na uwagę zasługuje dyskusja na temat genezy i chronologii reliktów kościoła odkrytego u podnóża Góry św. Wawrzyńca (Sikorski 2012). W tym miejscu należy stanowczo podkreślić, że wbrew formułowanym domysłom nie ma podstaw, aby chronologię budowy tego niedokończonego obiektu odnosić do 1. połowy XII wieku czy też 1. ćwierci XIII stulecia i wiązać je dopiero z działalnością biskupa Chrystiana. Abstrahując od dyskusyjnych, rzecz jasna, argumentów dotyczących stylistyki i technik budowlanych zastosowanych przy wznoszeniu tej budowli należy stwierdzić, że poszczególne partie fundamentów czy też murów przykryte są nawarstwieniami zawierającymi „,czyste” zespoły ceramiki przyporządkowanej do faz VII i VIII datowanych na okres od XI/XII do 1. połowy XII wieku. Ich chronologia została jednoznacznie potwierdzona w wielu miejscach badanego zespołu osadniczego bogatego w importy, znaleziska monetarne i liczne datowania radiowęglowe, które mimo swojego relatywizmu stanowią jeden z ważnych filarów datowania archeologicznego.

Znacznie lepiej zachowały się ślady osadnictwa z fazy IX na osadzie podgrodowej, pełniącej w tym czasie funkcje rzemieślniczo-handlowe, również dzięki wyposażeniu jej w karczmę i targ. Odkryto tu kilkaset obiektów osadniczych pochodzących z tego okresu, a wśród nich relikty dużego budynku naziemnego w konstrukcji słupowo-sumikowej (obiekt 172) z wyraźnie wyodrębnionym podcieniem, wybudowanego w miejscu wcześniejszego budynku (obiekt 240). Ta ciągłość użytkowanej działki może wskazywać także na ciągłość funkcji opisywanego obiektu, który z uwagi na usytuowanie przy drodze dojazdowej do grodu oraz gabaryty zinterpretowano jako pozostałość karczmy wzmiankowanej 
w falsyfikacie mogileńskim. W jego pobliżu odkryto liczne przedmioty wskazujące na status społeczno-zawodowy mieszkańców tej części osady. Oprócz licznych żelaznych ostróg i grotów strzał, świadczących o przebywaniu tu wojów, odkryto wiele przedmiotów związanych z kulturą symboliczną (krzyżyki), luksusową biżuterią (kamienie półszlachetne) oraz rozrywką (kostki i kamienie do gry). To wokół pozostałości karczmy koncentrowała się największa liczba dobrze datowanych śladów wytwórczości rzemieślniczej, między innymi metalurgii kolorowej i czarnej (liczne odpadki produkcyjne srebra i ołowiu, forma odlewnicza do kabłączków skroniowych, dysza) i rogownictwa. Na uwagę zasługują wyjątkowo licznie występujące materialne świadectwa wymiany handlowej, o czym przekonują utensylia kupieckie, przede wszystkim odważniki i fragmenty pojedynczych brązowych wag. Charakterystyczna jest również duża liczba monet, oprócz młodszych typów denarów krzyżowych w nawarstwieniach z tego okresu odkryto denary Bolesława Kędzierzawego bite w latach 1157-1166; występowały one zarówno na grodzisku, osadzie podgrodowej, jak i na cmentarzysku. Na szczególną uwagę zasługuje skład bardzo dobrze zachowanych 16 monet tego władcy, znaleziony w obiekcie 1030. W sumie odkryto ponad 40 monet zalegających w kilkunastu obiektach odsłoniętych w różnych częściach osady podgrodowej, wskazujących jednoznacznie na jej handlowy charakter.

Problemem pozostaje synchronizacja nawarstwień z IX fazy odkrytych na grodzisku i osadzie. Niestety, współczesna archeologia, oprócz tradycyjnej metody typologiczno-porównawczej, nie posiada narzędzi do bardziej szczegółowego rozwarstwienia chronologicznego zespołów naczyń ceramicznych zalegających po obu stronach Góry św. Wawrzyńca. Wydaje się jednak, że odkryte na południe od Góry materiały są zasadniczo starsze niż bardziej zaawansowane technologicznie i stylistycznie, charakterystyczne dla zespołów tzw. przejściowych, związane z najmłodszym horyzontem piecowisk na grodzisku. Ten domysł musi zostać jednak zweryfikowany w wyniku szczegółowej analizy technologiczno-stylistycznej ceramiki zalegającej w tych nawarstwieniach.

W opisywanym okresie użytkowane były również dwie części cmentarza, obrzeża najstarszej nekropoli oraz eoliczne wyniesienie nieopodal Góry św. Wawrzyńca. Na taką chronologię wskazują monety: trzy brakteaty o niejasnej proweniencji, znane - jak dotąd - jedynie ze skarbu we Wieńcu na Kujawach (groby 116, 77 i warstwa), interpretowane jako wytwór mennictwa wdowy po Kazimierzu Sprawiedliwym - Heleny, księżniczki znojemskiej (1194-1200) (Musiałowski 2010, s. 141) oraz brakteat z wizerunkiem Angelusa, datowany na 1. ćwierć XIII wieku, wyprodukowany najpewniej w jednej z mennic śląskich, charakterystyczny dla tego obszaru (Musiałowski 2006). Z punktu widzenia powiązań Chełmna z księciem śląskim Henrykiem odkrycie tej monety jest bardzo cenne. W świetle odkryć archeologicznych i źródeł pisanych gród chełmiński jawi się w 1. ćwierci XIII wieku jako naczelny ośrodek gospodarczy i polityczny 
ziemi chełmińskiej, którego znaczenie trudno przecenić. O jego powiązaniach dalekosiężnych, śląskich czy niemieckich świadczą niektóre importy odnajdywane w różnych częściach opisywanego zespołu.

Lokacja Chełmna w 1233 roku wprowadziła nowy porządek prawno-ustrojowy, a kasztelania przestała de facto istnieć (Jóźwiak 1996). Jednak, jak dotąd, brakuje materiałów źródłowych ze Starogrodu, odzwierciedlających ten pierwszy etap miasta lokacyjnego. Oczywiście można zadać pytanie: czy w ogóle kilka lat funkcjonowania tego ośrodka - w przedziale od 1233 do 1239 roku - musiało zaznaczyć się w pozostałościach materialnych wykrywalnych metodami archeologicznymi. Problem ten dotyczy między innymi ufundowanego w tym okresie przez zakon krzyżacki klasztoru Dominikanów z kościołem pod wezwaniem św. św. Piotra i Pawła, odgrywającego istotną rolę w organizacji misji wśród Prusów (Czaja 2006, s. 142), czy też najstarszego kościoła parafialnego Wniebowzięcia Najświętszej Marii Panny, uposażonego w przywileju lokacyjnym z 1233 roku. Dopóki nie zostaną przeprowadzone systematyczne badania na terenie Starogrodu to kwestia ta pozostanie otwarta. Problemem na razie nie do rozwiązania na gruncie archeologii jest również pierwsza translokacja miasta w $1239 \mathrm{roku}$; czy odbyła się ona circa Vislam w okolice dzisiejszego Starogrodu, czy na teren Rybaków w obrębie dzisiejszego Chełmna? Przywilej z 1251 roku dotyczy oczywiście Chełmna, w miejscu gdzie ono znajduje się dzisiaj, zaznaczającego się w krajobrazie przyrodniczo-kulturowym swoim średniowiecznym układem przestrzennym, architekturą kościelną, klasztorną i murami miejskimi, które w zasadniczym zrębie powstały w 2. połowie XIII wieku (m.in. klasztor cysterek i benedyktynek oraz kościół św. Jana Chrzciciela i św. Jana Ewangelisty, kościół i szpital św. Ducha). Wyjaśnienia na gruncie badań interdyscyplinarnych wymaga też problem kolejnych translokacji miasta, których przyczyn dopatrywać się należy również wśród czynników przyrodniczych związanych z dynamiką lokalnego reżimu hydrograficznego (Kordowski 2004).

Mimo zasadniczych różnic ustrojowych pomiędzy zurbanizowanym w dużym stopniu ośrodkiem kasztelańskim w 2. połowie XII i w 1. ćwierci XIII wieku a ośrodkiem miejskim zakonu krzyżackiego, odzwierciedlającymi dwie fazy urbanizacji omawianego terytorium, warto jednak zwrócić uwagę na elementy kontynuacji w funkcjonowaniu tego osiedla miejskiego przenoszonego wzdłuż krawędzi wysoczyzny na odcinku zaledwie kilku kilometrów. Warto podkreślić stołeczną rangę tego ośrodka pełniącego - niezależnie od zmieniających się uwarunkowań prawno-ustrojowych - centralne funkcje polityczne, religijne, społeczno-gospodarcze i kulturotwórcze. W przypadku obu etapów jego rozwoju było to również najważniejsze w regionie miejsce wymiany i produkcji o dalekosiężnych powiązaniach interegionalnych, którego kontynuacją w XIV wieku wydaje się udział Chełmna w związku hanzeatyckim. Również układ gród-miasto charakterystyczny jest dla obu etapów. Nie można też wykluczyć częściowej 
kontynuacji biologicznej mieszkańców Chełmna, pochodzenia mazowieckiego, w okresie krucjat pruskich zasilonego ludnością z terytorium Śląska, Czech, Moraw, Niemiec i Danii, natomiast po lokacji zdominowanego przez ludność niemiecką. Kontynuacja widoczna jest również w przypadku nazwy ośrodka Chełmno (niem. Culm, stpol. chełm - góra, wzniesienie), przenoszonej wraz z translokacjami, której pierwotny, toponimiczny charakter związany z Górą św. Wawrzyńca wydaje się dobrze uzasadniony.

\section{Literatura}

Bieniak J.

$1970 \quad$ Studia nad dziejami ziemi chetmińskiej wokresie piastowskim, Rocznik Grudziądzki, t. 5/6, s. 5-69.

Chudziak W.

2003 Wczesnośredniowieczna przestrzeń sakralna in Culmine na Pomorzu Nadwiślańskim, Mons Sancti Laurentii, t. 1, Toruń.

2010 Chetmno/Kulm - Genese und Funktion einer frühmittelalterlichen Stadt, Acta Praehistorica et Archaeologica, t. 42, s. 19-40.

Czaja R.

2006 Pierwsze pięćset lat Chetmna (1232-1772), [w:] M. Chełminiak, Chetmno zabytkami malowane, Bydgoszcz, s. 69-196.

Jasiński T.

1980 Pierwsze lokacje nad Wista. 750 lat Torunia i Chetmna, Torun.

1992 Okoliczności nadania ziemi chetmińskiej krzyżakom w 1228 roku w świetle dokumentu łowickiego, [w:] Balticum. Studia z dziejów polityki, gospodarki i kultury XII-XIV wieku ofiarowane Marianowi Biskupowi w siedemdziesiata rocznicę urodzin, red. Z. H. Nowak, Toruń, s. 151-163.

Jóźwiak S.

1996 Translokacje Chetmna a powstanie komturstw staro- $i$ nowochetmińskiego, [w:] Studia nad dziejami miast i mieszczaństwa w średniowieczu. Studia ofiarowane Profesorowi Antoniemu Czacharowskiemu w sześćdziesiąta piata rocznice urodzin i czterdziestolecie pracy naukowej, red. R. Czaja, J. Tandecki, Toruń, s. 83-94.

Kola A.

1975 Wczesnośredniowieczne Chełmno w świetle źródeł archeologicznych. Problem pierwotnej lokalizacji, cz. 1, maszynopis rozprawy doktorskiej w Instytucie Archeologii UMK, Torun.

Kordowski J.

2004 Osady i rzeźba doliny Wisty w okolicach Chetmna i Świecia, [w:] Wczesnośredniowieczny zespót osadniczy w Kałdusie. Studia przyrodniczo-archeologiczne, Mons Sancti Laurentii, t. 2, red. W. Chudziak, s. 43-68. 
Musiałowski A.

2006 Monety, [w:] Wczesnośredniowieczne cmentarzysko szkieletowe w Kałdusie (stanowisko 1), Mons Sancti Laurentii, t. 3, red. W. Chudziak, Toruń, s. 105-106.

2010 Analiza numizmatyczna wczesnośredniowiecznych monet, [w:] Wczesnośredniowieczne cmentarzysko szkieletowe w Kałdusie (stanowisko 4), Mons Sancti Laurenti, t. 5, red. W. Chudziak, Toruń, s. 137-157.

Noryśkiewicz A.

2013 Historia roślinności i osadnictwa ziemi chetmińskiej w późnym holocenie. Studium palinologiczne, Toruń.

Nowak Z. H.

1987 Dzieje Chetmna do końca XVIII wieku, [w:] Dzieje Chetmna. Zarys monograficzny, red. M. Biskup, Warszawa, s. 64-68.

Powierski J.

1973 Studia nad strukturą administracyjno-terytorialna ziemi chetmińskiej i michałowskiej w okresie piastowskim, Bydgoskie Towarzystwo Naukowe, Prace Wydziału Nauk Humanistycznych, seria C, nr 13, Prace Komisji Historii 9, s. 3-86.

Sikorski D. A.

2012 Wczesnopiastowska architektura sakralna (jako źródło historyczne do dziejów Kościoła w Polsce), Poznań.

Ślaski K.

1960 Podzialy terytorialne Pomorza w XII-XIII w., Poznań.

Wyrwa A. M.

2002 Bischof Christian und seine nicht verwirklichte Stiftung in Preussen; Altenberger Blätter. Beiträge aus der Vergangenheit und Gegencrant Altenbergs, t. 45 , s. 46-62.

2009 Alberyk z Trois-Fontaines o początkach chrześcijaństwa w Prusach, [w:] Studia z dziejów średniowiecza ofiarowane Profesorowi Bronisławowi Nowackiemu, red. Z. Górczak, J. Jaskulski, Poznań, s. 69-99.

THE 'LONG' $13^{\text {TH }}$ CENTURY IN CHEEMNO

Summary

Complex processes that took place in the north-western part of the Slavs' territory in the $13^{\text {th }}$ century, essentially ones that changed the existing traditional model of community, influenced many spheres of life, including the most important socio-economic and political transformations. In the case of Chełmno Land which was a borderland located between Mazovia, Kujawy, Eastern Pomerania and Old Prussian Pomezania, in its structure referring to German marches, these processes can be characterized by a few keywords such as 'feudalization', 'decentralization/centralization', 'colonization' or 'urbanization'. The history of Chełmno Land in the second half of the $12^{\text {th }}$-first half of the $13^{\text {th }}$ century, which is described relatively well in written sources, can be followed in particular on the 
example of Chełmno, the centre of this area. The name is eponymous with regard to the whole region, which clearly emphasizes its exceptional importance. In the history of this centre's 'moving' in geographical terms according to the will of the then policy-makers, fundamental socio-economic and political transformations were enacted, creating the symbolic 'long' duration of the $13^{\text {th }}$ century. Located at the crossroads of long-distance trade routes, on the western outskirts of the Vistula, Drwęca and Osa River basins, it was for a long period a 'gateway' to Chełmno Land. The political and socio-economic centre was to be on the border periphery, initially of the Polish state within the castellan organization, and then of the Teutonic Order, at least in the first stage of its being.

The primary role of Chełmno in the region between the Vistula, Drwęca and Osa Rivers is also confirmed by the results of archaeological research conducted intensively in Chełmno Land for many decades (Kola 1975; Chudziak 2003, 2010 - therein earlier literature). They have generally been carried out in two separate areas, traditionally distinguished in Polish archaeology: one concerning early medieval settlement (Kałdus) and the second, focusing on the study of late medieval culture that was generally associated with the history of the Teutonic Order in this area (Starogród and Chełmno).

Despite the significant organizational differences between the strongly urbanized castellan centre in Kałdus/Chełmno in the second half of the $12^{\text {th }}$ and the first quarter of the $13^{\text {th }}$ century and the urban centre of the Teutonic Order, reflecting two urbanization phases of this area, it should be noted that the elements of continuation in this working urban settlement transferred along the edge of the height over a distance of only a few kilometres. It is worth noting the capital rank of this area that acted, regardless of the changing legal and political system - as a centre of political, religious, socio-economic and cultural functions. In the case of both stages of its development it was also the most important place in the region for exchange and production, with long-distance connections, a continuation of which in the $14^{\text {th }}$ century, seems to have been the participation of Chełmno in the Hanseatic League. 